\title{
Determining the Degree of Service Quality, Customer Satisfaction and Loyalty: An Empirical Study of Retail Banking in Ghana
}

\author{
Daniel Kasser Tee ${ }^{1 *}$, Alexander Preko², Evans Tee ${ }^{3}$ \\ ${ }^{1}$ PhD Candidate, Accra Institute of Technology (AIT)/Open University Malaysia (OUM) \\ ${ }^{2}$ Lecturer, University of Professional Studies, Accra (UPSA) \\ ${ }^{3}$ Lecturer, Department of Business Administration, Regentropfen College of Applied Sciences (ReCAS) \\ *Corresponding Author: Daniel Kasser Tee, PhD Candidate, Accra Institute of Technology (AIT)/Open \\ University Malaysia (OUM)
}

\begin{abstract}
The intangible nature of services makes it difficult for an organisation to understand how its customers perceive and evaluate the quality of its services. The pressing need for banks to ensure customer satisfaction and loyalty makes it imperative for them to assess their service quality levels. The purpose of this study was to determine the degree of service quality, customer satisfaction and loyalty among retail banking customers in Ghana. The GAP analysis technique was applied to help in identifying the strengths or deficiencies in the service quality, customer satisfaction and customer loyalty levels, as judged by respondents. The results showed that the extent of Service Quality in Ghana's banking industry is reasonably high. Also, the extent of Customer Satisfaction, which was rated, based on the single item question, recorded a higher rating over and above service quality. The mean score for Overall Customer Loyalty was 5.08 (Gap score=1.92), indicating a slightly high rate of customer loyalty among bank customers in Ghana. Overall, Customer Loyalty has a relatively high Gap score of 1.92, compared with Service Quality (Gap = 1.75) and customer satisfaction (Gap of 1.50). This points to the existence of lower levels of customer loyalty for the Ghana banking industry, followed by service quality and then customer satisfaction. The study further concluded that the Ghanaian banks should particularly pay attention to behavioural loyalty to help improve on the overall customer loyalty.
\end{abstract}

Keywords: Service Quality, Customer Satisfaction, Customer Loyalty, Retail Banking

\section{INTRODUCTION}

Service industries are playing an increasingly important role in the overall economies of both developed and developing countries (Angelova and Zekiri, 2011). The services sector of every country therefore contributes significantly to its economic development, as service remains one of the three key components of gross domestic product (GDP), with the two other sectors being agriculture and industry. Currently, there is a growing importance of the services sector in the world economy (Arasli et al., 2005), as compared to the other two sectors. The Central Intelligence Agency (2014) world factbook estimates that services contributed $63.5 \%$ of world gross domestic product (GDP) in 2014 . The estimates for Ghana, from the same study are; agriculture $21.4 \%$, industry $29.2 \%$ and services $49.4 \%$. Over the years, researchers have tried to define service in slightly different ways. Wei (2013) gives a relatively modern definition as an activity or a series of activities in intangible form which usually takes place between customers and service providers.

Services, unlike physical products, generally exhibit characteristics of intangibility, inseparability, heterogeneity and perceived risk, that set them apart from physical products (Bitran and Lojo, 1993, Zeithaml and Bitner, 1996). The implications of these characteristics are that it is often difficult for customers to evaluate services at pre-consumption, consumption and post-consumption stages of the consumer decision-making process (Legg and Baker, 1996). The intangible nature of services makes it difficult for an organisation to understand how its customers perceive and evaluate the quality of its services (Parasuraman et al., 1985). Customers, however, make inferences about service quality based on other tangible issues such as the state of buildings, physical layout and décor in and around the service environment, and these have significant impact on customers' affective responses and their behavioural intentions (Dabholkar et al., 1996, Wakefield and Blodgett, 1999). 
The complex nature of services, coupled with the growing prominence of the services sector, has also increased the need for organisations to improve service quality. In view of this, service quality is increasingly recognized as one of the key strategic values of organisations in both the manufacturing and service sectors (Lewis, 1991). Service quality results in the satisfaction and possible retention of customers and employees, which could lead to a reduction in customer attrition and employee turnover as well as encourage repeat purchase behaviour and attract new customers through positive recommendations, (Caruana, 2002, Lewis, 1991, Newman, 2001, Wang et al., 2003). In Ghana today, the banking industry is characterised by heightened competition, customer sophistication, technological advancement, general high cost of doing business, easy availability of substitute products and stiffer regulatory regimes.

The combined effects of these are dwindling incomes and rising costs, and hence affecting profits adversely. Banks therefore require stellar service quality to beat out the competition, as high levels of service quality is said to lead to improved customer satisfaction, loyalty, market share growth and higher financial performance. Agreeing with these, Radomir et al. (2011) opined that; high service quality leads to competitive advantage as customers feel satisfied and thus are more probable to further buy the company's services, to recommend them to others and to ignore the competitors' offer. It is therefore necessary to continuously measure service quality in order to establish those areas that need improvement. Researchers generally share the view that service quality is an important tool for measuring customer satisfaction (Kadir et al., 2011). Service quality has a clear positive and significant impact on customer satisfaction (Ming, 2003) and also influences the financial performance of companies (Ashiqullah, 2006). Many researchers (Firdaus et al., 2011, Mukesh et al., 2010, Parasuraman et al., 1985) believe that service quality is an elusive concept, and there are considerable arguments among researchers on how to conceptualise this phenomenon.

From the above, the main objective of this study is to establish the applicability of the known five dimensions of service quality and also determine the degree of service quality, customer satisfaction and loyalty among retail banking customers in Ghana. The specific questions to be answered therefore are;

- What constitutes service quality in retail banking?

- What is the extent of service quality, customer satisfaction and loyalty prevalent in retail banking?

- In what ways are retail banking customers loyal to their banks?

\section{LITERATURE REVIEW}

\subsection{Service Quality}

Service quality is acknowledged as a 'critical prerequisite for establishing and sustaining satisfying relationships with valued customers' (Lassar et al., 2000, p.244). Many researchers believe that service quality is an elusive concept, and there are considerable arguments among researchers on how to conceptualise it. It is a subjective phenomenon that hinges on the individual perceptions of customers (Schneider and White, 2004), and this explains why there is a high number of definitions attributed to service quality (Radomir et al., 2011). Some recent definitions of service quality include; the consumer's overall impression of the relative inferiority or superiority of a company and its services (Siddique et al., 2011), a measure of the extent to which the service delivered fulfils the customers' expectations (Wei, 2013), customer's judgment about a service (Culiberg and Rojšek, 2010) and the difference between customers' expectations of service and their perceptions of actual service performance (Zeithaml and Parasuraman, 2004), among others. It is also acknowledged in literature that service quality is a dynamic, multidimensional concept, incorporating a number of aspects of both past and present service experiences (Ab.Aziz et al., 2014). Literature is replete with research findings that service quality remains a critical factor in the success of most businesses. Kadir et al. (2011) opine that service quality is an important tool for measuring customer satisfaction and also influences performance of companies. High service quality leads to competitive advantage as customers feel satisfied and thus are more probable to further buy the company's services, to recommend them to others and to ignore competitors' offers (Radomir et al., 2011). It is therefore necessary to continuously measure service quality in order to establish those areas that need improvement". 


\subsubsection{Assessing Service Quality}

The most widely used models for measuring service quality in the banking sector are the SERVQUAL and SERVPERF models (Shanka, 2012). The SERVQUAL framework was developed by Parasuraman et al. (1988), based on their own gap model, Parasuraman et al. (1985). Since the introduction of SERVQUAL, many researchers have used, extended or further developed the scale to study service quality in different sectors of the services industry (Adil et al., 2013, Buttle, 1996, Newman, 2001). The SERVPERF scale by Cronin and Taylor (1992) is one such improvement over the SERVEQUAL scale. Unlike the SERVQUAL, which identifies gaps between customers' expectations (E) and their perceptions of the performance (P) of services, the SERVPERF measures service quality, using perceptions only. Based on its overwhelming adoption and usage in recent studies (Beerli, 2004, Lee and Hwan, 2005, Mensah, 2010, Sulieman, 2011, Wang, 2003, Zahoor, 2011), this study uses the SERVPERF scale to measure the service quality in Ghana's banking industry.

\subsection{Customer Satisfaction}

Customer satisfaction has been gaining increasing attention from researchers and practitioners as a recognized field of scholarly study as well as a fundamental tool used by financial institutions for enhancing customer loyalty and, ultimately, organisational performance and profitability (Mohsan et al., 2011). The subject remains an important factor in the performance and competitiveness of banks (Belás et al., 2015, Chavan and Ahmad, 2013, Keisidou et al., 2013), as they seek to grow their businesses sustainably. Munari et al. (2013) posit that comprehensive customer care and the bank customer satisfaction agenda is currently at the centre of attention of researchers and bankers as it represents an important marketing variable for most companies. Hsien-Ta et al. (2010) defined customer satisfaction as the gap between customer expectations and perceptions regarding service quality, whilst Farris et al. (2010) defined satisfaction as the percentage of total customers, whose reported experience with a firm, its products or services exceeds expected satisfaction goals. On their part, Dominici and Guzzo (2010) defined customer satisfaction as a business philosophy which tends to the creation of value for customers, anticipating and managing their expectations, and demonstrating ability and responsibility to satisfy their needs.

\subsubsection{Assessing Customer Satisfaction}

Customer satisfaction has been gaining increasing attention as a recognized field of scholarly study as well as a fundamental tool used by financial institutions for enhancing customer loyalty and, ultimately, organisational performance and profitability (Mohsan et al., 2011). Although confusion still exists between the two concepts of service quality and customer satisfaction, several authors have pointed to their differences (Radomir et al., 2011). Synthesising the various definitions of customer satisfaction, leads to the conclusion that customer satisfaction is an attitude or behaviour that customers vocalize or exhibit post-consumption. Being a determinant of satisfaction, most researchers have used the five dimensions of service quality to measure customer satisfaction. In this study, however, customer satisfaction was measured by soliciting responses to a single question: "Overall, I am satisfied with this bank". The problems associated with the use of a single response variable were mitigated by the simplicity of the question; the suggestion by Yi (1990) that a single overall satisfaction measure score, is "reasonably valid" (p. 71).

\subsection{Customer Loyalty}

Customer loyalty is a concept that has enjoyed wide currency and usage within the field of consumer behaviour for many years (Saeed et al., 2011). Customer loyalty has attracted the interest of managers and researchers alike in the recent past (Khan, 2012). Researchers point to many benefits an organisation can derive as a result of improving loyalty levels (Zairi, 2009). This has consequently led companies to initiate various measures to increase the loyalty of their customers (Khan, 2012). Despite efforts to make customers more loyal, researchers have found that even 'loyal' customers are willing to switch, if provided with the appropriate opportunity (Khan, 2012). This has led researchers to believe that loyalty research has been unable to produce 'generalizable' results as we do not fully understand the concept of loyalty from a customers' perspective (Khan, 2012).

\subsubsection{Assessing Customer Loyalty}

There exist slightly different approaches for determining customer loyalty by researchers and practitioners. In their study on customer loyalty assessment in Iran, Dehghan and Shahin (2011) 
Determining the Degree of Service Quality, Customer Satisfaction and Loyalty: An Empirical Study of Retail Banking in Ghana

compiled several of the applicable questionnaire used by previous researchers for measuring customer loyalty. These included Butcher et al. (2001), Chaudhuri and Holbrook (2001), Colwell et al. (2009), Foster and Cadogan (2000), Kassim and Abdullah (2010), McMullan (2005), Pedersen and Nysveen (2001), Sirdeshmukh et al. (2002), Taylor et al. (2004), Thuy and Hau (2010), Wong (2004), Wong and Sohal (2003). Most of these previous works classified their questionnaires according to the type of customer loyalty being evaluated. Synthesising these resources, therefore, the customer loyalty questionnaire for this study was composed of 13 questions on behavioural loyalty and 14 emotional loyalty questions.

\section{Methodology}

\subsection{Research Design and Sampling Procedures}

Quantitative research paradigm emphasizes the importance of generalizability and reliability (Henn et al., 2006) in the choice of a sample, which ought to be statistically representative. Based on this, a sample size of 1,020 was used, from which a total of 850 usable questionnaires were generated for this study. This was deemed appropriate as a sample size of between 200 and 500 is generally accepted for SEM analysis (Phau and Shanka (2014).

\subsection{Survey Instrument}

This study employed a survey questionnaire to collect raw data from bank customers for analysis. The questionnaire was made up of initial 10 questions, covering the key profiles of respondents and 22 service quality questions per the Cronin and Taylor (1992) SERVPERF scale. Customer satisfaction was measured by soliciting responses to a single question: "Overall, I am satisfied with this bank", while customer loyalty was measured with 13 questions on behavioural loyalty and 14 on emotional loyalty, drawn from several research works cited in Dehghan and Shahin (2011).

\subsection{Data Analysis}

To determine the degree of service quality, customer satisfaction, and customer loyalty, the study employed the gap analyses technique. This techniques was applied to help in identifying the strengths or deficiencies in the service quality, customer satisfaction and customer loyalty, as judged by respondents.

Table1. Descriptive Statistics and Service Quality/ Satisfaction Gaps

\begin{tabular}{|c|c|c|c|c|c|c|c|}
\hline \multicolumn{3}{|c|}{ Service Quality Variables } & $\mathbf{N}$ & Mean & Std. Deviation & Std. Error Mean & Gap \\
\hline Q1 & \multirow{4}{*}{ Tangibility } & $\mathrm{T} 1$ & 849 & 5.44 & 1.32 & 0.05 & 1.56 \\
\hline $\mathrm{Q} 2$ & & $\mathrm{~T} 2$ & 850 & 5.48 & 1.25 & 0.04 & 1.52 \\
\hline Q3 & & T3 & 848 & 5.77 & 1.14 & 0.04 & 1.23 \\
\hline $\mathrm{Q} 4$ & & $\mathrm{~T} 4$ & 844 & 5.39 & 1.31 & 0.05 & 1.61 \\
\hline Q5 & \multirow{5}{*}{ Reliability } & R5 & 848 & 5.05 & 1.46 & 0.05 & 1.95 \\
\hline Q6 & & R6 & 845 & 5.18 & 1.36 & 0.05 & 1.82 \\
\hline Q7 & & R7 & 845 & 5.1 & 1.47 & 0.05 & 1.9 \\
\hline Q8 & & $\mathrm{R} 8$ & 847 & 5.09 & 1.43 & 0.05 & 1.91 \\
\hline Q9 & & R9 & 842 & 5.05 & 1.53 & 0.05 & 1.95 \\
\hline Q10 & \multirow{4}{*}{ Responsiveness } & RS10 & 847 & 5.18 & 1.39 & 0.05 & 1.82 \\
\hline Q11 & & RS11 & 846 & 5.12 & 1.39 & 0.05 & 1.88 \\
\hline Q12 & & RS12 & 848 & 5.27 & 1.36 & 0.05 & 1.73 \\
\hline Q13 & & RS13 & 848 & 5.07 & 1.45 & 0.05 & 1.93 \\
\hline Q14 & \multirow{4}{*}{ Assurance } & A14 & 829 & 5.29 & 1.29 & 0.05 & 1.71 \\
\hline Q15 & & A15 & 832 & 5.57 & 1.28 & 0.04 & 1.43 \\
\hline Q16 & & A16 & 830 & 5.31 & 1.33 & 0.05 & 1.69 \\
\hline Q17 & & A17 & 827 & 5.42 & 1.24 & 0.04 & 1.58 \\
\hline Q18 & \multirow{5}{*}{ Empathy } & E18 & 831 & 5.06 & 1.43 & 0.05 & 1.94 \\
\hline Q19 & & E19 & 831 & 5.41 & 1.43 & 0.05 & 1.59 \\
\hline Q20 & & E20 & 831 & 5.05 & 1.41 & 0.05 & 1.95 \\
\hline Q21 & & E21 & 829 & 5.17 & 1.44 & 0.05 & 1.83 \\
\hline Q22 & & E22 & 828 & 5.09 & 1.39 & 0.05 & 1.91 \\
\hline \multicolumn{4}{|c|}{ Total Service Quality } & 5.25 & 1.37 & 0.05 & 1.75 \\
\hline Q23 & Satisfaction & CS23 & 796 & 5.5 & 1.33 & 0.05 & 1.5 \\
\hline
\end{tabular}

Source: Survey data, 2016

NB: Mean scores computed from the average of the indicators of each construct 
Table 1 shows the gap (difference) between the maximum measurement scale item and the mean scores associated with each indicator of service quality, customer satisfaction and loyalty. The larger the difference or gap score, the lower the level of perceived service quality, satisfaction or loyalty. In this regard, variables with higher gap scores need more urgent or require critical management attention.

\section{FINDINGS/RESULTS}

It is observed that all the 22 service quality indicators had mean scores higher than 5 , an indication that service quality is reasonably high for each of the 22 items. A variable like T3 (followed by A15, $\mathrm{T} 2$ and $\mathrm{T} 1)$ has one of the largest mean scores $($ Mean $=5.77$, Std. Dev. $=1.14)$ and consequently one of the lowest gap scores $(\mathrm{Gap}=1.23)$. On the other hand, a variable like R5 (also R9 and E20) has one of the lowest mean scores (mean $=5.05$; Std. Dev. $=1.46$ ) and hence one of the largest gap scores $(\mathrm{Gap}=1.95)$. Generally, T4 (Gap=1.61), A14 (Gap=1.71), A16 (Gap=1.69), and RS12 (Gap=1.73) are moderate performers with gap scores that are slightly lower than the average gap of 1.75 .

Twelve variables, comprising R5, R6, RS10, RS11, R7, R8, R9, R13, E18, E20, E21 and E22 have large gap scores (ranging from 1.82 to 1.95 ) and therefore reflect relatively low level of perceived quality. The top six attributes with small gap scores are T3: $(\mathrm{Gap}=1.23), \mathrm{A} 15$ : $(\mathrm{Gap}=1.43), \mathrm{T} 2$ : $(\mathrm{Gap}=1.52)$, T1: $(\mathrm{Gap}=1.56), \mathrm{A} 17:(\mathrm{Gap}=1.58)$ and E19: $(\mathrm{Gap}=1.59)$, an indication that these attributes attracted the highest ratings from customers. From Table 2, the overall service quality gap of 1.75 is larger than the customer satisfaction gap of 1.5, demonstrating that the source of satisfaction goes beyond satisfaction with service quality attributes.

Table2. Ranking of Attribute Means and Quality Gaps

\begin{tabular}{|l|c|c|c|c|c|}
\hline \multicolumn{7}{|l|}{ Ranking of Attribute Means and Quality Gaps } \\
\hline VARIABLE & $\mathbf{N}$ & Mean & Std. Deviation & Std. Error & Gap \\
\hline TANGIBLES & 843 & 5.52 & 1.04 & 0.04 & 1.48 \\
\hline ASSURANCE & 824 & 5.39 & 1.06 & 0.04 & 1.61 \\
\hline RESPONSIVENESS & 844 & 5.16 & 1.13 & 0.04 & 1.84 \\
\hline EMPATHY & 826 & 5.15 & 1.13 & 0.04 & 1.85 \\
\hline RELIABILITY & 837 & 5.10 & 1.12 & 0.04 & 1.90 \\
\hline TOTAL SERVICE QUALITY & $\mathbf{8 4 9}$ & $\mathbf{5 . 2 5}$ & $\mathbf{1 . 3 7}$ & $\mathbf{0 . 0 5}$ & $\mathbf{1 . 7 5}$ \\
\hline SATISFACTION & $\mathbf{7 9 6}$ & $\mathbf{5 . 5 0}$ & $\mathbf{1 . 3 3}$ & $\mathbf{0 . 0 5}$ & $\mathbf{1 . 5 0}$ \\
\hline
\end{tabular}

Source: Survey Data, 2016

Tangibles was rated highest by bank customers, followed by Assurance, Responsiveness, Empathy, with Reliability being last as illustrated on Table 2 .

Table 3 shows the Gap scores associated with customer loyalty and its indicators. It can be seen that the largest Gap score is associated with EL14: "No account with any other bank" (Mean = 3.99, Std. Dev. $=2.26$; Gap = 3.01) followed by EL15: "Committed and unwilling to accept other banks" (Mean $=4.00$, Std. Dev. $=1.95$; Gap = 3.00) and EL25: "Will not switch, even if I had a problem with this bank" $($ Mean $=4.15$, Std. Dev. $=1.82 ;$ Gap $=2.85)$. All three bottom placed indicators are from the Emotional Loyalty sub category.

Table3. Descriptive Statistics and Customer Loyalty Gaps

\begin{tabular}{|l|l|l|c|c|c|c|}
\hline & QUESTION ASKED & N & Mean & Std.Deviation & Gap \\
\hline & & I continue to patronise this bank because; & & & & \\
\hline \multirow{3}{*}{} & BL1 & Their service quality gives me total satisfaction & 844 & 5.30 & 1.35 & 1.70 \\
\cline { 2 - 7 } & BL2 & Of some other reasons but not total satisfaction & 843 & 4.92 & 1.51 & 2.08 \\
\cline { 2 - 7 } & BL3 & Of their products and services & 843 & 5.28 & 1.35 & 1.72 \\
\cline { 2 - 7 } & BL4 & Their interest rates are favourable to me & 844 & 4.92 & 1.50 & 2.08 \\
\cline { 2 - 7 } & BL5 & Of their image, adverts, branding, word-of-mouth & 844 & 4.94 & 1.52 & 2.06 \\
\cline { 2 - 7 } & BL6 & Their branches are close to me & 845 & 5.06 & 1.69 & 1.94 \\
\cline { 2 - 7 } & BL7 & Their extensive branch network & 844 & 5.10 & 1.50 & 1.90 \\
\cline { 2 - 7 } & BL8 & Of the attitudes of their staff & 844 & 4.99 & 1.46 & 2.01 \\
\cline { 2 - 7 } & BL9 & Of the absence of any better alternatives & 843 & 4.22 & 1.81 & 2.78 \\
\cline { 2 - 7 } & BL10 & I believe other banks may be worse than this & 842 & 4.42 & 1.80 & 2.58 \\
\hline
\end{tabular}


Determining the Degree of Service Quality, Customer Satisfaction and Loyalty: An Empirical Study of Retail Banking in Ghana

\begin{tabular}{|l|l|l|l|l|l|l|}
\hline BL11 & $\begin{array}{l}\text { Something always holds me back, each time I think } \\
\text { of leaving this bank }\end{array}$ & 840 & 4.53 & 1.70 & 2.47 \\
\hline BL12 & Of some reasons, other than loyalty & 830 & 4.60 & 1.73 & 2.40 \\
\hline BL13 & Of their external visibility & 838 & 5.08 & 1.65 & 1.92 \\
\hline \multicolumn{1}{|c|}{ Total Behavioural Loyalty } & $\mathbf{8 4 2}$ & $\mathbf{4 . 8 6}$ & $\mathbf{0 . 9 4}$ & $\mathbf{2 . 1 4}$ \\
\hline & 819 & 3.99 & 2.26 & 3.01 \\
\hline EL14 & No accounts with any other bank & 837 & 4.00 & 1.95 & 3.00 \\
\hline EL15 & Committed and unwilling to accept other banks & 838 & 5.09 & 1.49 & 1.91 \\
\hline EL16 & I often say things about this bank & 838 & 5.21 & 1.40 & 1.79 \\
\hline EL17 & I will recommend this bank to anyone & 836 & 5.23 & 1.51 & 1.77 \\
\hline EL18 & I deal with this bank because I want to, not because & I have to & 834 & 4.65 & 1.79 & 2.35 \\
\hline EL19 & Doesn't not matter which staff serves me & 824 & 4.98 & 1.53 & 2.02 \\
\hline EL20 & This bank is the best choice for me & 824 & 4.71 & 1.55 & 2.29 \\
\hline EL21 & I have emotional connection to this bank & 823 & 5.06 & 1.44 & 1.94 \\
\hline EL22 & Relationship is very important to me & 824 & 4.78 & 1.59 & 2.22 \\
\hline EL23 & I will do anything just to maintain this relations & 823 & 4.47 & 1.71 & 2.53 \\
\hline EL24 & Will maintain business even if their prices change & 823 & 4.15 & 1.82 & 2.85 \\
\hline EL25 & Will not switch, even if I had a problem & 823 & 4.74 & 1.60 & 2.26 \\
\hline \multirow{2}{*}{$\begin{array}{l}\text { EL26 } \\
\text { Will keep business, if I had to do it all over again }\end{array}$} \\
\hline EL27 & Has exceptional image, compared to others & 824 & 5.03 & 1.39 & 1.97 \\
\hline EL28 & I have great respect for the image of this bank & 823 & 5.37 & 1.34 & 1.63 \\
\hline
\end{tabular}

At the other extreme end are the attributes with lower gap scores and hence relatively better rating for loyalty. These include EL28: "I continue to bank here because I have great respect for the bank's image" $($ Mean $=5.37$, Std. Dev. $=1.34$, Gap = 1.63), BL1: "I continue to bank here because their service quality gives me total satisfaction" (Mean $=5.30$, Std. Dev. $=1.35$, Gap =1.70) and BL3: "I continue to bank here because of their products and services" (Mean $=5.28$, Std. Dev. $=1.35$, Gap $=$ 1.72). The first of these top three attributes comes from Emotional Loyalty while the second and third are Behavioural Loyalty dimensions.

\section{DisCUSSIONS}

The extent of Service Quality in Ghana's banking industry is reasonably high, judging from the findings. Overall Service Quality was rated with a high mean score of 5.25 (Gap score=1.75). On the basis of the above, customers generally rated bank Service Quality high for the industry, with individual mean scores of each service quality dimension being higher than the scale mean of 5 . This is similar to the findings by Aruban Banking Association and Centrale Bank Van Aruba (2013). The results also showed that eleven banks were rated above the industry average (Mean=5.25) with the remaining six falling short of this measure.

Two banks that require critical attention for service quality improvement are HFC (Mean=4.72, $\mathrm{Gap}=2.28$ ) and Baroda (Mean=4.76, Gap=2.24), as they fell below the scale mean of 5. The best service quality indicators for the industry, by way of performance above the average score, were only ten. These include; T3 (This Bank's front-line employees are neat and well dressed), A15 (I feel safe in my transactions with this Bank), T2 (This Bank's physical facilities are visually appealing), T1 (This Bank has modern-looking equipment), A17 (Employees in this Bank have the requisite knowledge to answer my questions), E19 (This Bank's operating hours are very convenient for me), T4 (Materials associated with the service: such as brochures, account statements etc. are visually appealing to me), A16 (Employees in this Bank are consistently courteous towards me), A14 (The behaviour of employees in this Bank gives me all the needed confidence to do business with them) and RS12 (Employees in this bank are always willing to help me). The remaining twelve items recorded mean scores lower than the scale mean, indicating low levels of service quality.

The extent of Customer Satisfaction, which was rated, based on the single item question (Overall, I am satisfied with this bank), recorded a higher rating over and above service quality. The findings 
reveal a relatively higher mean rating of 5.50 (Gap score 1.5), which is an indication of high customer satisfaction rate. This is in line with the findings of Bhatta and Singhal (2015), Haq and Muhammad (2012), Lohani and Bhatia (2012) who found similar high satisfaction rates. Nine banks performed below this average mean score of 5.5, with Zenith and FBN banks scoring below the scale mean of 5.0. The difference between the service quality mean score of 5.25 and the customer satisfaction mean score of 5.50 further demonstrates that the source of satisfaction goes beyond satisfaction with service quality attributes and therefore require further research. Eight banks received better ratings than the industry average mean score for satisfaction.

The mean score for Overall Customer Loyalty towards banks was 5.08 (Gap score=1.92), compared with the scale mean of 5.0. This indicates a slightly high rate of customer loyalty among bank customers. This finding is in line with the work of Aruban Banking Association and Centrale Bank Van Aruba (2013) who also found high loyalty among bank customers. With regards to the type of loyalty, Emotional Loyalty received a relatively higher mean score of 5.29 (Gap score=1.71) compared with the Behavioural Loyalty mean of 4.86 (Gap score=2.1.4). Based on these findings, it is advisable for the management of banks to improve customer loyalty rates by working to narrow the individual gap scores towards zero for the customer loyalty scale. They are particularly advised to pay attention to behavioural loyalty, as the mean score for this loyalty dimension is below the scale mean and therefore indicating lack of loyalty.

\section{CONCLuSion}

Most of the respondents rated the quality of services provided by their banks as very high. Overall Customer Loyalty has a relatively high Gap score of $1.92($ Mean $=5.08$, Std. Dev. = 1.62), compared with Service Quality Gap $=1.75($ Mean $=5.25$, Std. Dev. $=1.37)$ and customer satisfaction Gap of $1.50($ Mean $=5.50$, Std. Dev. $=1.33)$. This points to the existence of lower levels of customer loyalty for the Ghana banking industry, followed by service quality and then customer satisfaction. The outcome from this study provides motivation and insights to managers in the retail banking industry to further work to improve customer satisfaction.

\section{REFERENCES}

[1] AB.AZIZ, M. R., SHUKOR, S. A. \& ABDULLAH, W. W. M. Z. 2014. A Specific Analysis of Service Quality Dimensions on Customer Satisfaction and Customer Loyalty: A Study of Al-Ijarah Thumma AlBai' (AITAB) and Vehicle Financing-i (Bai' Bithaman Ajil-BBA). Journal of Emerging Issues in Economics, Finance and Banking (JEIEFB); An Online International Monthly Journal, 3.

[2] ADIL, M., AL GHASWYNEH, O. F. \& ALBKOUR, A. M. 2013. SERVQUAL and SERVPERF: a review of measures in services marketing research. Global Journal of Management and Business Research Marketing, 13, 64-76.

[3] ANGELOVA, B. \& ZEKIRI, J. 2011. Measuring Customer Satisfaction with Service Quality Using American Customer Satisfaction Model (ACSI Model). International Journal of Academic Research in Business and Social Sciences, 1.

[4] ARASL1, H., KAT1RC1OĞLU, S. T. \& MEHTAP-SMADI, S. 2005. A Comparison of Service Quality in the Banking Industry: Some Evidence from Turkish- and Greek-speaking Areas in Cyprus. International Journal of Bank Marketing, 23, 508-526.

[5] ARUBAN BANKING ASSOCIATION \& CENTRALE BANK VAN ARUBA. 2013. Commercial Banks' Customer Satisfaction Survey Results (http://www.cbaruba.org/cba/readBlob.do?id=2602). [Accessed November 7, 2016].

[6] ASHIQULLAH, S. 2006. A relational study on automated service quality, customer satisfaction and financial performance in the context of Bank Asia Ltd available at: ww.sb.iub.edu.bd/internship/ summer2 006/0320454.pdf (accessed January 28, 2016). Summer internship report submitted to IUB University, Bashundhara.

[7] BEERLI, A. 2004. A Model of Customer Loyalty in the Retail Banking Market. European Journal of Marketing, 38, 253 - 275.

[8] BELÁS, J., CHOCHOLÁKOVÁ, A. \& GABČOVÁ., L. 2015. Satisfaction and Loyalty of Banking Customers: A Gender Approach. Economics and Sociology, 8, 176-188.

[9] BHATTA, K. R. \& SINGHAL, B. P. 2015. Customer Satisfaction in the Commercial Banks with Special Reference to Nepal. International Journal of Research in Computer Application \& Management (http://ijrcm.org.in/), 5. 
[10] BITRAN, G. \& LOJO, M. 1993. A framework for analysing the quality of the customer interface. European Management Journal, 11, 385-396.

[11] BUTCHER, K., SPARKS, B. \& O'CALLAGHAN, F. 2001. Evaluative and relational influences on service loyalty. International Journal of Service Industry Management, 12, 310-327.

[12] BUTTLE, F. 1996. Servqual: review, critique, research agenda. European Journal of Marketing, 30, 8-32.

[13] CARUANA, A. 2002. Service loyalty: the effects of service quality and the mediating role of customer satisfaction. European Journal of Marketing, Vol. 36 No. 7/8, pp. 811-28., 36, 811-28.

[14] CENTRAL INTELLIGENCE AGENCY. 2014. The World Factbook (online). South Africa. [Online]. Available: https://www.cia.gov/library/publications/resources/the-world-factbook/geos/sf.html [Accessed June 2015.

[15] CHAUDHURI, A. \& HOLBROOK, M. 2001. The chain of effects from brand trust and brand effect to brand performance: the role of brand loyalty. Journal of Marketing, 65, 81-93.

[16] CHAVAN, J. \& AHMAD, F. 2013. Factors Affecting on Customer Satisfaction in Retail Banking: An Empirical Study. International Journal of Business and Management Invention, 2, 55-62.

[17] COLWELL, S., HOGARTH-SCOTT, A., JIANG, D. \& JOSHI, A. 2009. Effects of organizational and serviceperson orientation on customer loyalty. Management Decision, 47, 1489-1513.

[18] CRONIN, J. \& TAYLOR, S. A. 1992. Measuring Service Quality: A Reexamination and Extension. Journal of Marketing, 56, 55-67.

[19] CULIBERG, B. \& ROJS`EK, I. 2010. Identifying service quality dimensions as antecedents to customer satisfaction in retail banking. Economic and Business Review, 12, 151-166.

[20] DABHOLKAR, P. A., THORPE, D. I. \& RENTZ, J. O. 1996. A measure of service quality for retail stores: scale development and validation. Journal of the Academy of Marketing Science, 24, 3-16.

[21] DEHGHAN, A. \& SHAHIN, A. 2011. Customer Loyalty Assessment, A Case Study in MADDIRAN, the Distributor of LG Electronics in Iran. Business Management and Strategy, 2.

[22] DOMINICI, G. \& GUZZO, R. 2010. Customer Satisfaction in the Hotel Industry: A Case Study from Sicily. International Journal of Marketing Studies; available at http://dx.doi.org/10.5539/ijms.v2n2p3, 2, 312.

[23] FARRIS, P. W., BENDLE, N. T., PFEIFER, P. E. \& REIBSTEIN, D. J. 2010. Marketing Metrics: The Definitive Guide to Measuring Marketing Performance, New Jersey, Upper Saddle River, Pearson Education, Inc.

[24] FIRDAUS, A., ROSITA, S., GLUMA, S. \& JAMIL, H. 2011. Bank service quality (BSQ) index. An indicator of service performance. International Journal of Quality \& Reliability Management, 28, 542-555.

[25] FOSTER, B. D. \& CADOGAN, J. W. 2000. Relationship selling and customer loyalty: an empirical investigation. Marketing Intelligence \& Planning, 18, 185-199.

[26] HAQ, W. U. \& MUHAMMAD, B. 2012. Customer Satisfaction :A Comparison of Public and Private Banks of Pakistan. IOSR Journal of Business and Management (IOSRJBM), 1, 1-5.

[27] HENN, M., WEINSTEIN, M. \& FOARD, N. 2006. A short introduction to social research, London, Sage.

[28] HSIEN-TA, L., JHIH-CHUN, J., CHIU, C. \& MENG-LONG, S. 2010. Dynamic Analysis of Internet Word-of-Mouth on Resort Hotels.

[29] KADIR, H. A., RAHMANI, N. \& MASINAEI, R. 2011. Impacts of service quality on customer satisfaction: Study of Online banking and ATM services in Malaysia. International Journal of Trade, Economics and Finance, 2, 1-9.

[30] KASSIM, N. \& ABDULLAH, N. A. 2010. The effect of perceived service quality dimensions on customer satisfaction, trust, and loyalty in e-commerce settings - A cross cultural analysis. Asia Pacific Journal of Marketing \& Logistics, 22, 351-371.

[31] KEISIDOU, E., SARIGIANNIDIS, L., MADITINOS, D. I. \& THALASSINOS, E. I. 2013. Customer satisfaction, loyalty and financial performance. International Journal of Bank Marketing, 31, 259-288.

[32] KHAN, O. 2012. Towards Understanding Customer Loyalty: An Empirical Study on Emotional Attachment. International Journal of Innovations in Business, 1.

[33] LASSAR, W. M., MANOLIS, C. \& WINSOR, R. D. 2000. Service Quality Perspectives and Satisfaction in Private Banking. Journal of Services Marketing, 14, 244-271.

[34] LEE, M. C. \& HWAN, I. S. 2005. Relationship among Service Quality, Customer Satisfaction and Profitability in the Taiwanese Banking Industry. International Journal of Management, 22, 635-648.

[35] LEGG, D. \& BAKER, J. 1996. Advertising strategies for service firms", in Lovelock, C.H., Services Marketing, Englewood Cliffs, NJ., Prentice Hall. 
[36] LEWIS, B. R. 1991. Service Quality: An International Comparison of Bank Customers' Expectations and Perceptions. Journal of Marketing Management, 7, 7-18.

[37] LOHANI, M. B. \& BHATIA, P. 2012. Assement of Service Quality in Public and Private Sector Banks of India with Special Reference to Lucknow City. International Journal of Science and Research publication, $2,1-7$.

[38] MCMULLAN, R. 2005. A multiple-item scale for measuring customer loyalty development. Journal of Services Marketing, 19, 470-481.

[39] MENSAH. 2010. Customer Satisfaction in the banking industry: A comparative Study of Spain and Ghana Unpublished PhD Dissertation

[40] MING, W. 2003. Assessment of E-service quality via E-satisfaction in E-commerce. The Electronic Journal of Information System in Developing Countries, 11, 1-4.

[41] MOHSAN, F., NAWAZ, M. M., KHAN, M. S., SHAUKAT, Z. \& ASLAM, N. 2011. Impact of Customer Satisfaction on Customer Loyalty and Intentions to Switch: Evidence from Banking Sector of Pakistan. International Journal of Business and Social Science, 2.

[42] MUKESH, K., FONG, T. K. \& VINCENT, C. 2010. Comparative evaluation of critical factors in delivering service quality of banks. International Journal of Quality \& Reliability Management, 27, 351377.

[43] MUNARI, L., LELASI, F. \& BAJETTA, L. 2013. Customer Satisfaction Management in Italian Banks. Qualitative Research in Financial Markets, 5, 139-160.

[44] NEWMAN, K. 2001. Interrogating SERVQUAL: a critical assessment of service quality measurement in a high street retail bank. International Journal of Bank Marketing, 19, 126-39.

[45] PARASURAMAN, A., ZEITHAML, V. A. \& BERRY, L. L. 1985. A Conceptual Model of Service Quality: Its Implications for the Future Research. Journal of Marketing, 49, 41-50.

[46] PARASURAMAN, A., ZEITHAML, V. A. \& BERRY, L. L. 1988. SERVQUAL: A Multiple Item Scale for Measuring Consumer Perceptions of Service Quality. Journal of Retailing, 64, 12-40.

[47] PEDERSEN, P. E. \& NYSVEEN, H. 2001. Shopbot banking: an exploratory study of customer loyalty effects. International Journal of Bank Marketing, 19(4), 19, 146-155.

[48] PHAU, I. \& SHANKA, T. 2014. Examining a consumption values theory approach of young tourists toward destination choice intentions. International Journal of Culture, Tourism and Hospitality Research, $8,125-139$.

[49] RADOMIR, L., WILSON, A. \& MIRCEA, S. A. 2011. Improving Bank Quality Dimensions to Increase Customer Satisfaction. Management and Marketing Journal, 9, 126-148.

[50] SAEED, I., NIAZI, M. A., ARIF, M. \& JEHAN, N. 2011. Antecedents of Customer satisfaction and its outcomes ; A study of Pakistani service sector. Interdisciplinary Journal of Contemporary Research in Business; ijcrb.webs.com, 3.

[51] SCHNEIDER, B. \& WHITE, S. 2004. Service Quality Research Perspectives, Thousand Oaks: CA, Sage.

[52] SHANKA, M. S. 2012. Bank Service Quality, Customer Satisfaction and Loyalty in Ethiopian Banking Sector. Journal of Business Administration and Management Sciences Research. Available online at http://www.apexjournal.org/JBAMSR 1, 001-009.

[53] SIDDIQUE, A. B., KARIM, K. S. \& RAHMAN, M. L. 2011. Customers' Perception about the Determinants of Service Quality of Foreign and Domestic Banks: An Empirical Study on Bangladesh. Journal of Business And Technology, 1-14.

[54] SIRDESHMUKH, D., SINGH, J. \& SABOL, B. 2002. Consumer trust, value, and loyalty in relational exchanges. Journal of Marketing, 66, 15-37.

[55] SULIEMAN 2011. Banking Service Quality Provided by Commercial Banks and Customer Satisfaction. American Journal of Scientific Research, 68-83.

[56] TAYLOR, S. A., CELUCH, K. \& GOODWIN, S. 2004. The importance of brand equity to customer loyalty. Journal of Product \& Brand Management, 13, 217-227.

[57] THUY, P. N. \& HAU, L. N. 2010. Service personal values and customer loyalty: a study of banking services in a transitional economy. International Journal of Bank Marketing, 28, 465-478.

[58] WAKEFIELD, K. L. \& BLODGETT, J. G. 1999. Customer response to intangible and tangible service factors. Psychology and Marketing, 16, 51-68.

[59] WANG, J. 2003. The Antecedents of Service Quality and Product Quality and their influences on Bank Reputation: Evidence from Banking Industry in China. Managing Service Quality, 13, 72-83.

[60] WANG, Y., LO, H. \& HUI, Y. V. 2003. The antecedents of service quality and product quality and their influences on bank reputation: evidence from banking industry in China. Managing Service Quality, 13, 72-83. 
[61] WEI, L. C. 2013. Determinants of Customer Satisfaction in Domestic Retail Banking Sector. Master of Business Administration, Universiti Tunku Abdul Rahman.

[62] WONG, A. 2004. The role of emotional satisfaction in service encounters. Managing Service Quality, 14, 365-376.

[63] WONG, A. \& SOHAL, A. 2003. Service quality and customer loyalty perspectives on two levels of retail relationships. Journal of Services Marketing, 17, 495-513.

[64] YI, Y. 1990. A critical review of consumer satisfaction, Chicago, IL.

[65] ZAHOOR. 2011. SERPERF Analysis in the Banking Services. Master theses, Karachi Institute of Economics and Technology

[66] ZAIRI, M. 2009. Excellence Tetralogy: The Inspired Customer. Bradford, European Centre for Best Practice Management, University of Bradford.

[67] ZEITHAML, V. A. \& BITNER, M. J. 1996. Services Marketing, New York, NY, McGraw-Hill.

[68] ZEITHAML, V. A. \& PARASURAMAN, A. 2004. Service Quality, USA, Marketing Science Institute.

\section{AUTHOR's BIOGRAPHY}

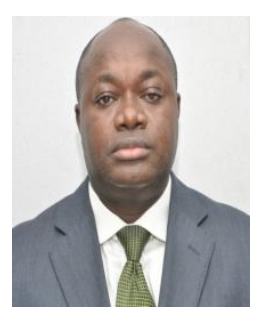

Daniel Kasser Tee is a Marketing and Corporate Communications practitioner with over 2 decades experience in Banking and Insurance. He is also a part-time Lecturer in Marketing and Project Management at the Accra Institute of Technology and Ghana School of Marketing. He is currently a PhD Candidate at the Open University Malaysia and holds separate MBA degrees in Strategic Marketing Management and Project Management. He is a full member of CIM (UK) and a Fellow of the American Academy of Project Management. His research interests are in Marketing of Financial Services, Service Marketing, Branding and CRM

Dr. Alexander Preko is a Lecturer in Marketing Research and Tourism Marketing at the Department of Marketing, University of Professional Studies, Ghana. He received his PhD in Management Economics and MSc in Marketing at the State University of Management, Moscow and his current research addresses the field of domestic tourism, youth tourism, educational tourism, tourism development and customer complaint behaviour. He has previously published in the Journal of Competitiveness.

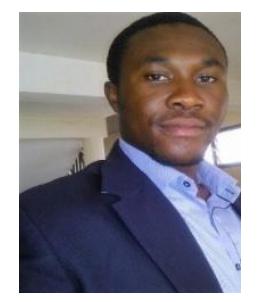

Evans Tee is a Lecturer at the Department of Business Administration, Regentropfen College of Applied Science (ReCAS), Kansoe, Ghana. He holds a Master of Philosophy degree in Business Administration (Risk Management and Insurance). His research interests are in quantitative research methods, risk management, business development, banking and financial markets.

Citation: Daniel Kasser Tee, Alexander Preko, Evans Tee. "Determining the Degree of Service Quality, Customer Satisfaction and Loyalty: An Empirical Study of Retail Banking in Ghana" International Journal of Managerial Studies and Research (IJMSR), vol 6, no. 3, 2018, pp. 44-53. doi:http://dx.doi.org/10.20431/ 2349-0349.0603006.

Copyright: (C) 2018 Authors. This is an open-access article distributed under the terms of the Creative Commons Attribution License, which permits unrestricted use, distribution, and reproduction in any medium, provided the original author and source are credited. 